九州大学学術情報リポジトリ

Kyushu University Institutional Repository

Influence on Water Status, Photosynthesis Rate and Plant Growth of Different Temperatures and Water Regimes during Pod Formation Phase of Mungbean

Miah, Md. Giashuddin

Department of Agronomy/Agroforestry and Environment, Institute of Postgraduate Studies in Agriculture (IPSA)

Hirota, 0samu

Institute of Tropical Agriculture, Kyushu University

Chikushi, Jiro

Biotron Institute, Kyushu University

https://doi.org/10.5109/24125

出版情報 : 九州大学大学院農学研究院紀要. 41 (1/2)，pp.17-28，1996-11. Kyushu University バージョン：

権利関係 : 


\title{
Influence on Water Status, Photosynthesis Rate and Plant Growth of Different Temperatures and Water Regimes during Pod Formation Phase of Mungbean
}

\author{
Md. Giashuddin Miah"1, Osamu Hirota ${ }^{* 2}$ and Jiro Chikushi ${ }^{* 3}$
}

\author{
Institute of Tropical Agriculture, Kyushu University, Fukuoka 812-81, Japan
}

(Received July 31, 1996)

\begin{abstract}
Effects of different temperatures and water regimes on soil and leaf water potential, photosynthesis, growth and dry matter production of mungbean during pod formation were examined in the phytotron growth chambers of the Kyushu University, Japan. Temperatures were $15,20,25$ and $30^{\circ} \mathrm{C}$ and water regimes were well irrigation and light irrigation. Almost all parameters (except root dry weight) of mungbean were much reduced in the light irrigated pots than those in the well irrigated pots irrespective of temperature gradients except 15 " $\mathrm{C}$. Effects of different temperature gradients were more pronounced in photosynthesis, plant height, number of pods per plant, total dry matter and dry matter accumulation in pods in the well irrigated pots; and soil water potential, leaf water potential, leaf area per plant and root dry matter in the light irrigated pots. In the well irrigated condition, $25{ }^{\circ} \mathrm{C}$ was found to be the most favorable for growth and development of mungbean, but in the light irrigated condition no definite temperature was found to be most favorable in all cases. It may be suggested that for getting higher photosynthesis, growth and dry matter production in mungbean an adequate soil moisture accompanied with $25{ }^{\circ} \mathrm{C}$ is the best environment for the plant.
\end{abstract}

\section{INTRODUCTION}

Mungbean (Vigna radiata L. Wilchzek) is a popular and important large seed grain legume because of its wide adaptability, high protein content and relatively short duration of growth (Lawn and Ahn, 1985). It is widely grown in Bangladesh and other Indian subcontinents and prefer warm temperature and moderate soil moisture for adequate growth and development. Although it is an important legume, its performance is poor mainly due to water and temperature stresses. Mungbean is grown under rainfed conditions so that it is often subjected to water stress (Hamid et al., 1990). The degree of water stress depends upon temperature gradients.

In mungbean it has been noticed that water as well as temperature stress occurring especially during flowering and pod formation causes considerable decrease of yield. Research activities that have been carried out in the past in Bangladesh were related mostly to variety, fertilizer, seed rate and spacing trials on the yield and yield components of mungbean. Very little information on the influence of temperature and water stresses on the growth, water status and photosynthesis is available.

The aim of this work was to assess the effects of four different temperatures and two moisture regimes in the phase of pod formation of mungbean on the leaf and soil water

Department of Agronomy/Agroforestry and Environment, Institute of Postgraduate Studies in Agriculture (IPSA), Salna, Gazipur, Bangladesh.

Institute of Tropical Agriculture, Kyushu University, Japan.

Biotron Institute, Kyushu University, Japan. 
potential, photosynthesis, plant growth and dry matter distribution.

\section{MATERIALS AND METHOD}

This study was carried out in the green house and Phytotron of the Kyushu University, Japan from October 1995 to January 1996. Uniform seeds of mungbean cultivar Pagasa-2 were sown on October 16, 1995 in $19 \times 16 \times 21 \mathrm{~cm}$ (top dia. $\times$ bottom dia. $\mathrm{x}$ height) plastic pots filled with sandy loam soils. The number of total pots were 106. A chemical fertilizer $\left(\mathrm{N}: \mathrm{P}_{2} \mathrm{O}_{5}: \mathrm{K}_{2} \mathrm{O}=16: 16: 16\right)$ of $10 \mathrm{~g}$ per pot was well mixed with the soil before planting the seeds. Immediately after sowing the seeds, an initial light irrigation was done in all pots so as to ensure uniform seedling establishment. Six seeds per pod were planted but on emergence the two seedlings of as far as possible the same size were kept in each pot. Thereafter, the plants were watered regularly to maintain adequate soil moisture conditions until the treatments were imposed.

Immediately before pod formation i.e., at 57 days after sowing of seeds, 32 pots (out of 106 pots) established uniformly were transferred into the phytotron (11 the December, 1995). Eight pots were placed in each of $15,20,25$ and $30^{\circ} \mathrm{C}$ growth chambers whose temperatures were constant. The soil moisture conditions were monitored by the tensiometer (SPAD, pF-33 type, Fujiwara Co.). Of the eight pots, four were well irrigated and the other were initially non-irrigated but later light irrigated as bellow. After the first measurement at 15 DATI(days after treatment imposition), the non-irrigated pots were irrigated when $\mathrm{pF}$ had reached to its maximum $(\mathrm{pF}=2.9)$ with $500 \mathrm{ml}$ of water, which was named as light irrigation treatment. In the irrigated pots, plants were irrigated with 500 $\mathrm{ml}$ of water at $\mathrm{pF}=1.5$. The relative humidity inside the chambers was maintained at $70 \%$. Natural solar radiation provided the light requirement.

Plants were sampled twice: at 15 and 30 DATI. During each sampling date, photosynthesis, soil and leaf water potentials, plant height, leaf area, the number of pods per plant, dry matter of stems, leaves, pods and roots were measured. Photosynthetic rates were measured one day before each sampling date between 10:00 AM to 3:00 PM. A fully expanded young leaf was used for the photosynthesis measurements using by portable photosynthesis measurement apparatus (ADC, UK). Measurement conditions were as follows; photosynthetic active radiation of $900 \mu \mathrm{mol} \mathrm{m} \mathrm{m}^{-2} \mathrm{~s}^{-1}$, air flow rate of $400 \mathrm{ml}$ $\min ^{-1}$ and the chamber temperature was changed to $15,20,25$ and $30^{\circ} \mathrm{C}$.

Leaf water potential of fully developed young leaves was measured with a thermocouple psychrometer (SC-10A, Decagon Devices). Soil water potential of $10 \mathrm{~cm}$ depth soil was measured with the same psychrometer. Leaf area was measured using a leaf area meter (Hayashi Denkoh Co.). Leaves, stems, pods and roots were dried in an oven at $80^{\circ} \mathrm{C}$ for 48 hours and those weight were measured.

\section{RESULTS AND DISCUSSION}

\section{Soil water potential}

A distinct variation in soil water potential due to variation in water regimes and 
temperatures was observed (Fig. 1). Soil water potential $\left(\psi_{\mathrm{s}}\right)$ was much lower in the light irrigated pots than those in the well irrigated pots except at $15^{\circ} \mathrm{C}$. Between two dates of measurement, $\psi_{s}$ in the irrigated condition did not vary significantly, but it had varied widely in the light irrigated pots except at $15^{\circ} \mathrm{C}$. In the irrigated pots, $\psi_{s}$ slightly decreased at the second measurement than that at the first measurement except at $30^{\circ} \mathrm{C}$ which $\psi_{\mathrm{s}}$ increased slightly at the second measurement (-4.25 bars) than at the first measurement (-4.97 bars). But in the light irrigated pots, $\psi_{\mathrm{s}}$ at the second measurement were unexpectedly increased compared with that at the first measurement which was due to application of water after the first measurement.

Among the temperature gradients, in general $\psi_{\mathrm{s}}$ decreased as the temperature gradient increased. But the differences were much more prominent in the light irrigated conditions than in the well irrigated condition. In the light irrigated condition, $\psi_{\mathrm{s}}$ at $15^{\circ} \mathrm{C}$ were -5.54 and -4.66 bars at 15 DATI and 30 DATI, whereas at $30^{\circ} \mathrm{C}$ it were -25.26 and -12.31 bars in the light irrigated, respectively. These wider variations under the light irrigated condition could be due to the combined effect of water and temperature stresses.

\section{Leaf water potential}

The changes of water potential in leaves due to different temperatures and water regimes were similar to those of soil water potential $\left(\psi_{\mathrm{s}}\right)$ with few exceptions (Fig. 2).

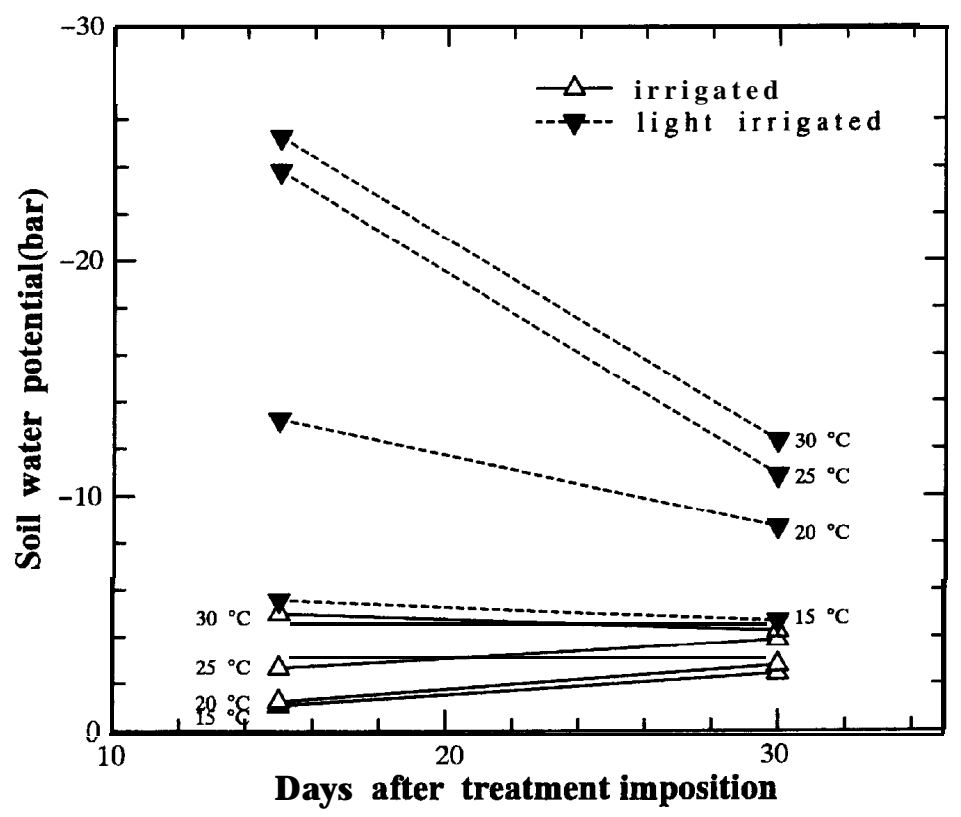

Fig. 1. Effect of temperatures and water regimes on the soil water potential of mungbean pots during pod formation stage. 


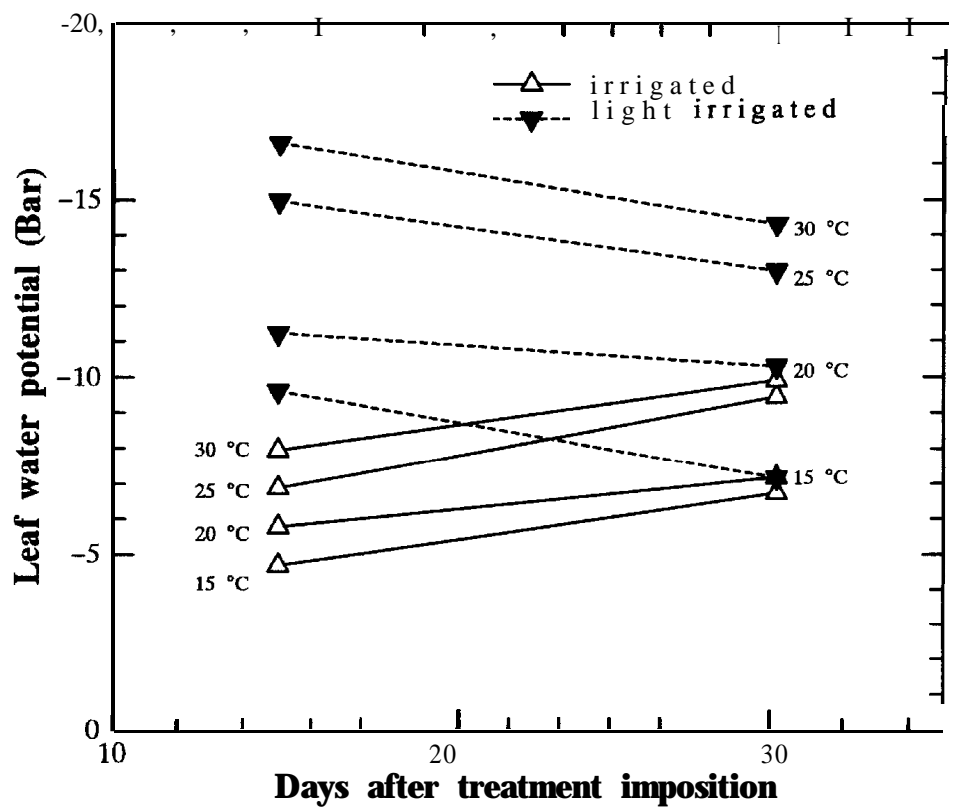

Fig. 2. Effect of temperatures and water regimes on the leaf water potential of mungbean during pod formation stage.

Leaf water potential $\left(\psi_{1}\right)$ in the light irrigated pots was much lower than that of the well irrigated pots, regardless of temperature gradients and date of measurements. The more negative values in the light irrigated condition at higher temperature gradients could be attributed to the cumulative effect of water and temperature stresses. The higher $\psi_{1}$ in the well irrigated plants was probably due to greater water extraction from the soil.

Similar to $\psi_{\mathrm{s}}$, the $\psi_{1}$ decreased as the temperature gradients increased irrespective of water regimes and dates of measurement. The rate of changes in $\psi_{1}$ as the temperature gradients increased was different in both the measurements. In the irrigated condition the rate of changes in $\psi_{1}$ was almost the same at 15 DATI, but at 30 DATI, the rate of changes in $\psi_{1}$ at $25^{\circ} \mathrm{C}$ and $30^{\circ} \mathrm{C}$ was higher than those of $20^{\circ} \mathrm{C}$ and $15^{\circ} \mathrm{C}$. In the light irrigated condition, the rate of changes at $25^{\circ} \mathrm{C}$ and $30^{\circ} \mathrm{C}$ was much higher than those of $20^{\circ} \mathrm{C}$ and $15^{\circ} \mathrm{C}$ at $15 \mathrm{DATI}$, but at $30 \mathrm{DATI}$, a much wider change was noted at $15^{\circ} \mathrm{C}$ than those of the other temperature gradients. As of $\psi_{\text {, }}$ (irrespective of temperature gradients), leaf water potential at the second measurement had decreased compared with the first measurement in the well irrigated condition, whereas in the light irrigated condition, leaf water potentials had increased in the second measurement than the first measurement. The increased leaf water potential in the second measurement under the light irrigated condition was due to application of water. 


\section{Photosynthesis}

The rate of photosynthesis in the light irrigated plants was much lower than that the well irrigated plants in both dates of measurement (Fig. 3). The mean net photosynthesis (average of four temperature gradients) in the light irrigated plants was only 27.7 and $59.8 \%$ of that in the well irrigated plants at 15 and 30 DATI, respectively. The much wider differences in net photosynthesis between the irrigated and the light irrigated plants at 15 DATI might be due to differences in soil water regimes, since no water was applied in the light irrigated pots up to 15 DATI. But the relatively closer values in the second date of measurement were due to application of water to the nonirrigated plants. Reduction of net photosynthesis under water stress conditions has been reported by Islam (1994), Hamid et al. (1990).

Marked differences were observed in net photosynthesis among the four temperature gradients in both the well irrigated and the light irrigated plants at both the measurements. In the well irrigated plants, the highest net photosynthesis was found at $20^{\circ} \mathrm{C}\left(19.4 \mu \mathrm{mol} \mathrm{m}^{-2} \mathrm{~s}^{-1}\right)$, followed by $25^{\circ} \mathrm{C}\left(17.3 \mu \mathrm{mol} \mathrm{m}^{-2} \mathrm{~s}^{-1}\right)$ and $30^{\circ} \mathrm{C}\left(15.7 \mu \mathrm{mol} \mathrm{m}^{-2} \mathrm{~s}-1\right)$,

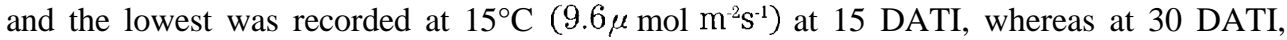
the net photosynthesis at $25^{\circ} \mathrm{C}\left(14.6, \sim \mathrm{mol} \mathrm{m} \mathrm{m}^{-2} \mathrm{~s}^{-1}\right)$ exceeded the net photosynthesis of $20^{\circ} \mathrm{C}\left(11.0 \mu \mathrm{mol} \mathrm{m}^{-2} \mathrm{~s}^{-1}\right)$, the net photosynthesis at $15^{\circ} \mathrm{C}$ remained the lowest. The relatively lower net photosynthesis in plants acclimated to higher temperature $\left(30^{\circ} \mathrm{C}\right)$ than lower temperatures $\left(20^{\circ} \mathrm{C}\right.$ and $\left.25^{\circ} \mathrm{C}\right)$ might have resulted from increased respiration

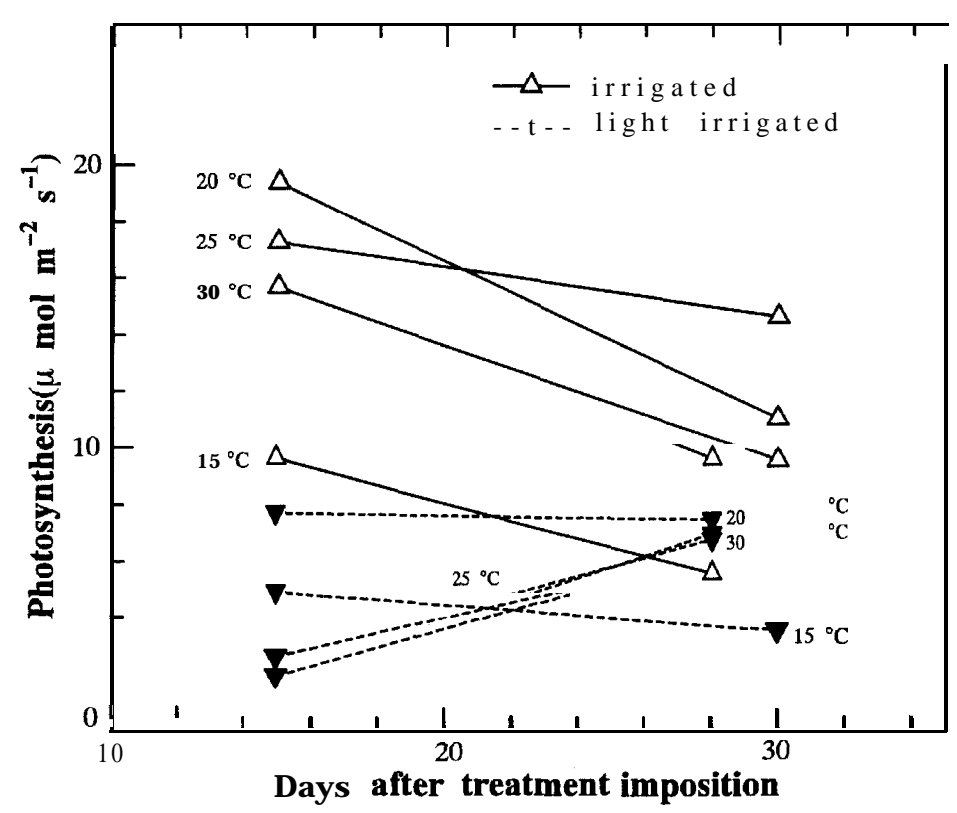

Fig. 3. Effect of temperatures and water regimes on the photosynthesis rate of mungbean during pod formation stage. 
(Jones, 1983). Similar view was also reported by Islam(1994). However, the overall net photosynthesis values in the second measurement, regardless of temperature gradients, were lower than those in the first measurement, since the crop advanced to the maturity stage.

In the light irrigated plants, plants subjected to $20^{\circ} \mathrm{C}$ had maintained the highest net photosynthesis at both measurements. The net photosynthesis of mungbean plants subjected to 25 and $30^{\circ} \mathrm{C}$ was much lower at 15 DATI, but dramatically increased at 30 DATI as the plants were rewatered. But the net photosynthesis at $15^{\circ} \mathrm{C}$ did not increase even when rewatered.

\section{Plant height, leaf area and pod number per plant}

Mungbeans grown in the well irrigated conditions at different temperature levels were taller than those of grown in the light irrigated conditions at the same temperature levels (Fig. 4). The comparatively lower plant height of mungbean in the light irrigated pots could be attributed to the combined effect of water and temperature stresses. Among the four temperature gradients, plants subjected to $30^{\circ} \mathrm{C}$ produced the tallest heights at both water regimes as well as at both dates of measurement. In the light irrigated condition, the height of the plants subjected to different temperature gradients did not vary significantly, ranged only from 22.2 to $22.7 \mathrm{~cm}$ at 15 DATI and 22.5 to $23.8 \mathrm{~cm}$ at 30 DATI. In the well irrigated condition, plants grown under $30^{\circ} \mathrm{C}$ were taller $(26.4 \mathrm{~cm})$ than those

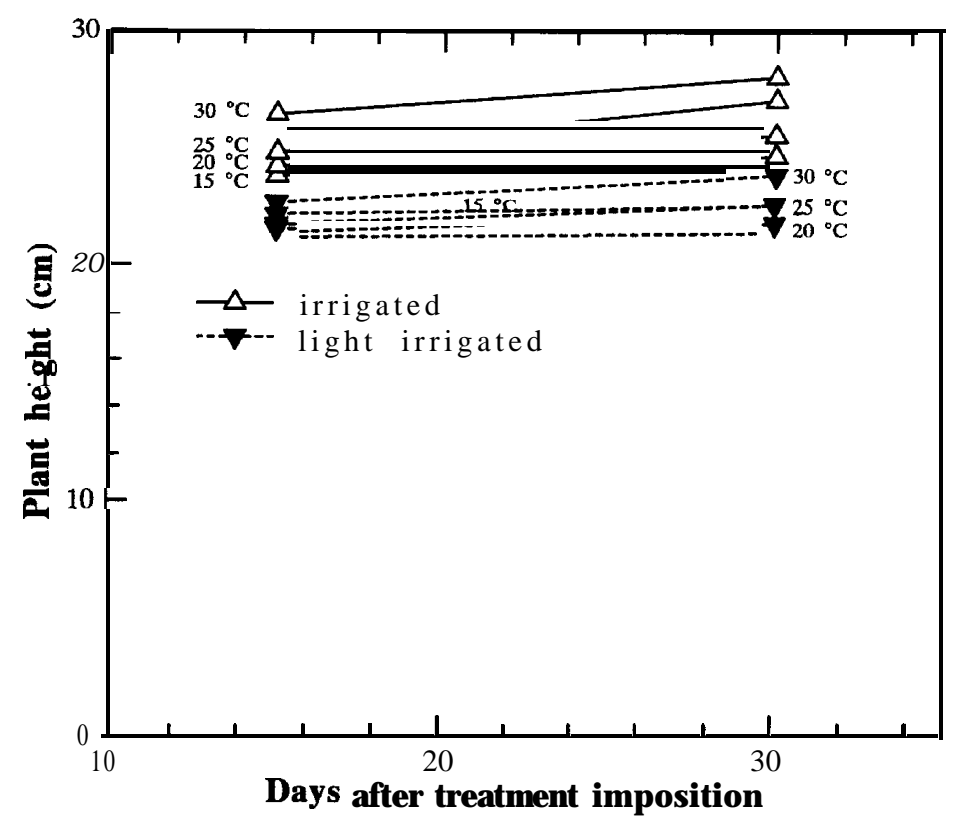

Fig. 4. Effect of temperatures and water regimes on the plant height of mungbean during pod formation stage. 
of grown under $25^{\circ} \mathrm{C}(24.8 \mathrm{~cm}), 20^{\circ} \mathrm{C}(24.2 \mathrm{~cm})$ and $15^{\circ} \mathrm{C}(23.8 \mathrm{~cm})$ at 15 DATI. At 30 DATI, plants grown under $30^{\circ} \mathrm{C}(28.0 \mathrm{~cm})$ as well as $25^{\circ} \mathrm{C}(27.0 \mathrm{~cm})$ were much taller than those grown under $20^{\circ} \mathrm{C}(25.5 \mathrm{~cm})$ and $15^{\circ} \mathrm{C}(24.6 \mathrm{~cm})$, reflecting the effect of temperatures in presence of adequate soil moisture.

The leaf area of mungbean in the light irrigated pots was markedly smaller than that in the well irrigated pots (Fig. 5). The average leaf area per plant of mungbean grown in the light irrigated pots (average of four temperatures) was 31 and $27 \%$ smaller than that of mungbean grown in the well irrigated pots at 15 and 30 DATI, respectively. Leaf area expansion is known to be sensitive to water deficiency (Legg et al., 1979). Among the different temperature gradients, no noticeable differences in leaf area per plant were noted in the well irrigated pots at both dates of measurement. Although differences were not so much in the well irrigated pots, the plants subjected to $30^{\circ} \mathrm{C}\left(366 \mathrm{~cm}^{2} /\right.$ plant $)$ and $20^{\circ} \mathrm{C}\left(391 \mathrm{~cm}^{2} /\right.$ plant $)$ produced the largest leaf area at 15 and 30 DATI, respectively. The plants subjected to $15^{\circ} \mathrm{C}$ produced the smallest leaf area (349 and $364 \mathrm{~cm}^{2} /$ plant) at both the measurements. Increased leaf area at high temperatures under the well irrigated condition implies increased cellular metabolism. Relatively marked differences in leaf area per plant were observed in the light irrigated pots where the leaf area values varied from $223\left(\right.$ at $30^{\circ} \mathrm{C}$ ) to $276 \mathrm{~cm}^{2}$ (at $15^{\circ} \mathrm{C}$ ) at $15 \mathrm{DATI}$, and 250 (at $30^{\circ} \mathrm{C}$ ) to $293 \mathrm{~cm}^{2}\left(25^{\circ} \mathrm{C}\right.$ ) at 30 DATI. It was noticed that the variation in leaf area due to moisture regimes was more pronounced than that of the temperature gradients. Leaf area was found to be

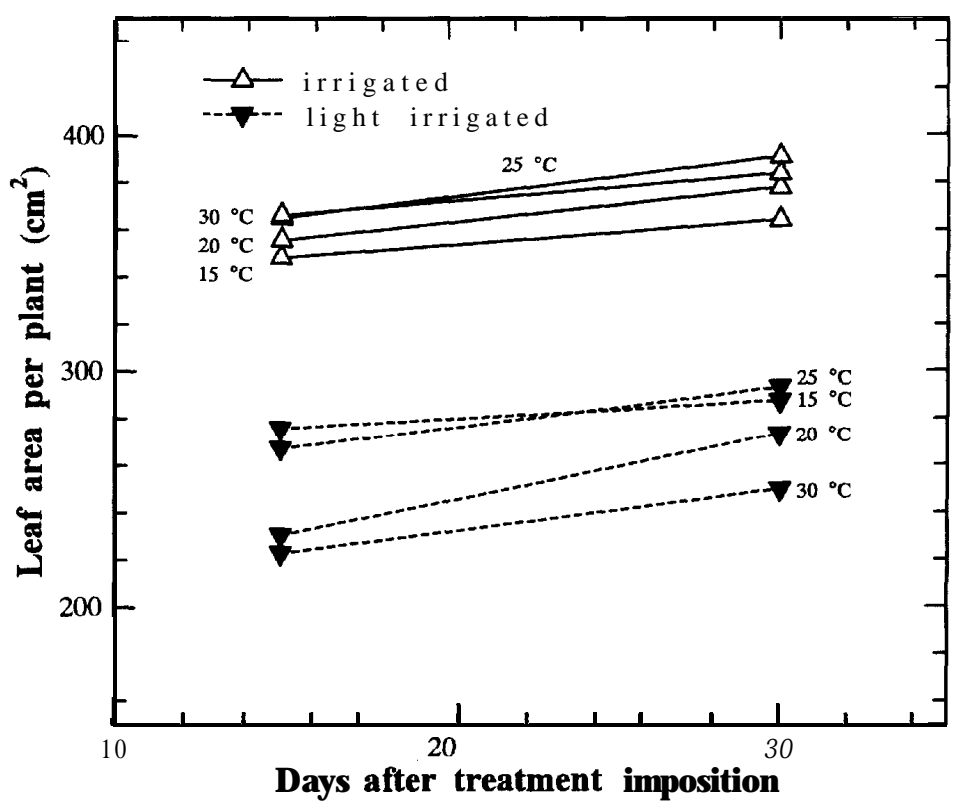

Fig. 5. Effect of temperatures and water regimes on the leaf area of mungbean during pod formation stage. 


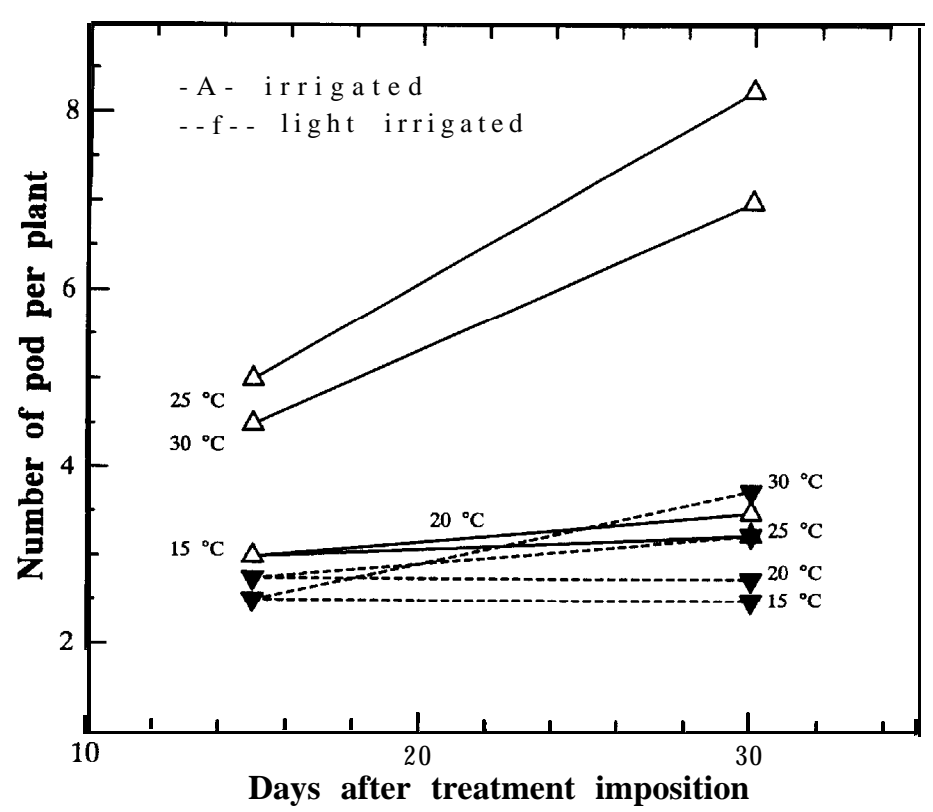

Fig. 6. Effect of temperatures and water regimes on the number of pods per plant of mungbean during pod formation stage.

highly influenced by the moisture stress that induced reduction in cell size and cell expansion, leaf size and the number of leaflets (Muchow, 1985).

The numbers of pods per mungbean plant grown at $25^{\circ} \mathrm{C}$ and $30^{\circ} \mathrm{C}$ in the well irrigated pots was remarkably higher than those of the other two temperature gradients at the same soil water regime and all temperature gradients in the light irrigated pots (Fig. 6). However, pod bearing ability at $25^{\circ} \mathrm{C}$ was more than that at $30^{\circ} \mathrm{C}$. The numbers of pods per plant at $25^{\circ} \mathrm{C}$ and $30^{\circ} \mathrm{C}$ temperatures in the well irrigated pots increased markedly from 5.0 and 4.5 at 15 DATI to 8.3 and 7.5 at 30 DATI, respectively, whereas at $20^{\circ} \mathrm{C}$ and $15^{\circ} \mathrm{C}$, these increased from only 3.0 and 3.0 at 15 DATI to 3.3 and 3.5 at 30 DATI. The pod bearing pattern of mungbean at lower temperature gradients (15 and 20 "C) in the well irrigated condition was similar to that even at higher temperature gradients in the light irrigated condition. Under acute water stress condition (at 15 DATI), the response of mungbean (in terms of the number of pods per plant) to different temperature gradients almost unchanged (varied only 2.5 to 2.7 pods per plant), but responded differently when the light irrigation was done where the number of pods per plant at $25^{\circ} \mathrm{C}$ and $30^{\circ} \mathrm{C}$ increased from 2.7 and 2.5 at 15 DATI to 3.3 and 3.8 at 30 DATI, respectively. The results revealed that performance of mungbean in terms of pod bearing ability was the best at $25^{\circ} \mathrm{C}$ under well irrigated condition. 


\section{Total dry matter}

Total dry matter production of mungbean at different temperature gradients except $15^{\circ} \mathrm{C}$ in the well irrigated pots was higher than that of the light irrigated pots irrespective of temperature gradients at both dates of measurement (Fig. 7). The reduction of total dry matter under water stress may be related to impaired photosynthesis. The higher dry matter production under the well irrigated condition may be due to the joint effect of the increased leaf area and photosynthetic activity. Similar views were reported by Kriedemann (1986), and Hamid et al. (1992). The magnitude of variation between the well irrigated and the light irrigated pots was more distinct at 30 DATI than that at 15 DATI. However, dry matter production at $15^{\circ} \mathrm{C}$ under the well irrigated condition was almost the same as those at $25^{\circ} \mathrm{C}$ and $30^{\circ} \mathrm{C}$ under the light irrigated conditions. Total dry matter production in mungbean increased as the time but the trend was more prominent at all temperature gradients except $15^{\circ} \mathrm{C}$ in the well irrigated pots and only $20^{\circ} \mathrm{C}$ in the light irrigated pots. However, in the well irrigated pots, mungbean grown at $25^{\circ} \mathrm{C}$ produced the highest total dry matter, whereas, in the light irrigated pots, mungbean grown at $20^{\circ} \mathrm{C}$ produced the highest total dry matter per plant. But both in the well irrigated and the light irrigated pots, mungbean grown at the lowest temperature $\left(15^{\circ} \mathrm{C}\right)$ produced the lowest total dry matter per plant. The highest dry matters produced at 25 ${ }^{\circ} \mathrm{C}$ in the well irrigated pots and at $20^{\circ} \mathrm{C}$ in the light irrigated pots were 5.72 and $4.04 \mathrm{~g}$ per plant, and the lowest dry matters produced at $15^{\circ} \mathrm{C}$ in both water regimes were 3.32 and

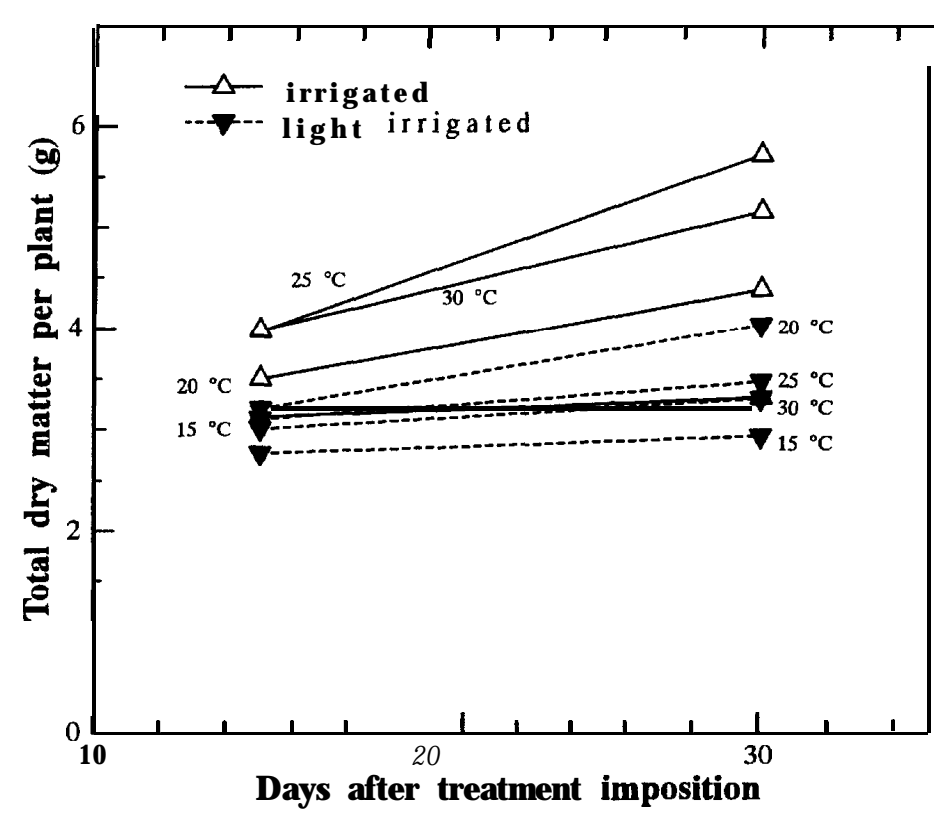

Fig. 7. Effect of temperatures and water regimes on the total dry matter production of mungbean during pod formation stage. 
$2.94 \mathrm{~g}$ per plant, respectively. The higher total dry matter at $25^{\circ} \mathrm{C}$ in the well irrigated pots and at $20^{\circ} \mathrm{C}$ in the light irrigated pots may be attributed largely to the pod dry weight of mungbean (Fig. 8)
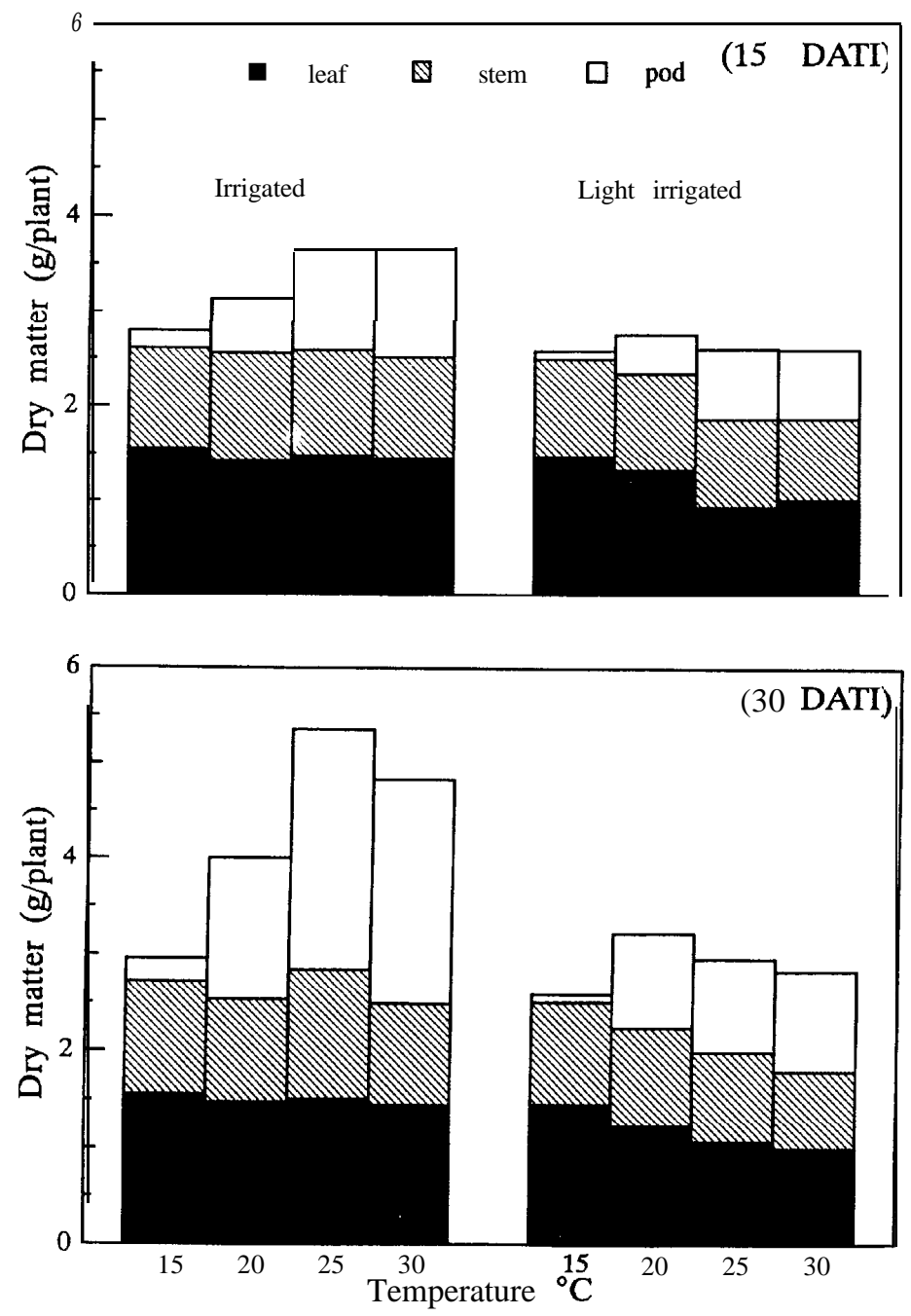

Fig. 8. Effect of temperatures and water regimes on the total dry matter distribution in eaf, stem and pods of mungbean during pod formation stage. 


\section{Dry matter distribution}

Leaf, stem and pod: Temperature gradients had different effects on the dry matter distribution of mungbean in different organs especially in pods under the both well irrigated and light irrigated conditions (Fig. 8). In the well irrigated pots, dry matter distribution pattern in leaf and stem of mungbean did not vary much in response to different temperature gradients, but a noticeable variation was observed in pods. Under these water regimes almost half of the dry matter accumulated in the pods at $25^{\circ} \mathrm{C}$ and 30 ${ }^{\circ} \mathrm{C}$, whereas only about one-tenth $(10 \%)$ of dry matter accumulated in the pods at $15^{\circ} \mathrm{C}$ at the final measurement (30 DATI). In the light irrigated pots, variation in dry matter distribution pattern in pod as well as leaf due to variation in temperature gradients was noticed. Under such water regime, dry matter accumulation in leaves slightly decreased as the temperature gradients increased; and about one-third of the dry matter accumulated in the pods at $20^{\circ} \mathrm{C}, 25^{\circ} \mathrm{C}$ and $30^{\circ} \mathrm{C}$, but very small amount of dry matter accumulated in the pods at $15^{\circ} \mathrm{C}$ at the final measurement (30 DATI). The relatively higher accumulation of dry matter in leaves at lower temperature $\left(15^{\circ} \mathrm{C}\right)$ may be due to the decreased translocation of the photosynthates to the pods.

Root: The dry matter accumulation in root of mungbean was higher under the light irrigated condition than that under the well irrigated condition except $15^{\circ} \mathrm{C}$ (Fig. 9). Higher accumulation of dry matter in roots under the light irrigated condition may be due to inhibition of translocation of carbohydrates from the roots to the pods and expanding

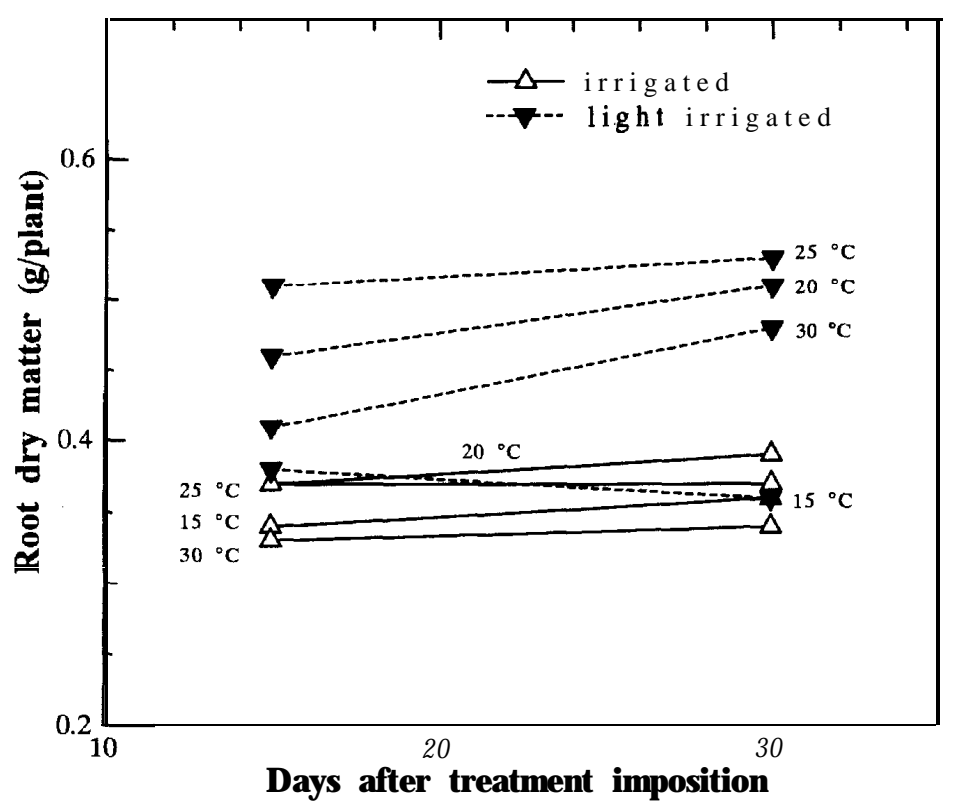

Fig. 9. Effect of temperatures and water regimes on the distribution of the total dry matter accumulation in root of mungbean during pod formation stage. 
of roots to meet the transpiration demand of plants. The influences of temperatures in root dry matter accumulation were more distinct in the light irrigated plants than the well irrigated plants. The root dry matter accumulation varied from $0.38 \mathrm{~g}\left(15^{\circ} \mathrm{C}\right)$ to $0.51 \mathrm{~g}$ $\left(25^{\circ} \mathrm{C}\right)$ per plant at $15 \mathrm{DATI}$, and from $0.36 \mathrm{~g}\left(15^{\circ} \mathrm{C}\right)$ to $0.52 \mathrm{~g}\left(25^{\circ} \mathrm{C}\right)$ at 30 DATI under the light irrigated condition. It varied from only $0.33 \mathrm{~g}\left(30^{\circ} \mathrm{C}\right)$ to $0.37 \mathrm{~g}$ (both 20 and 25 “C) per plant at $15 \mathrm{DATI}$, and $0.34 \mathrm{~g}\left(30^{\circ} \mathrm{C}\right)$ to $0.39 \mathrm{~g}\left(20^{\circ} \mathrm{C}\right)$ at $30 \mathrm{DATI}$ under the well irrigated condition.

\section{REFERENCES}

Hamid, A., F. Kubota, W. Agata and M. Morokuma 1990 Photosynthesis, transpiration, dry matter accumulation and yield performance of mungbean in response to water stress. J.Fac. Agr., Kyushu Univ., 35(1-2): 81-92

Hamid, A., Q. R. Islam and W. Agata 1992 Varietal differences in stomatal size and frequency and their effects on gas exchange in mungbean. Bangladesh J. Bot. 2: 269-272

Islam, M. T. 1992 Eco-physiological Studies on Photosynthesis and Dry Matter Production in Mungbean. A. PhD. Thesis. Kyushu University, Japan

Jones, H. G. 1983 Plants and Microclimate: A Quantitative Approach to Environemental Plant Physiology. Camb. Univ. Press, Camb, London, New York, New Rochelle, Melbourne, Sydney

Kriedemann, P. E. 1986 Stomatal and photosynthetic limitations to leaf growth. Aust. J. Plant Physiol., 13: $15-31$

Lawn, R. J. and C. S. Ahn 1985 Mungbean, In "Grain Legume Crops", ed. by R. J. Summerfield and E. H. Roberts, Collins, UK, pp. 584-623

Legg, B. J., W. Day, D. W. Lawlor and K. J. Parkinson 1979 The effects of drought on barley growth: models and measurements showing the relative importance of leaf area and photosynthetic rate. $J$. Agric. Sci. 92: 703-716

Muchow, R. C. 1985 Canopy development in grain legumes grown under different soil water regimes in a semi-arid tropical environments. Field Crops Res., 11(1): 99-109 